doi:10.4149/neo_2016_002

\title{
Circulating cell-free DNAs and miRNAs as promising non-invasive biomarkers for early detection of gastric cancer
}

\section{Minireview}

X. LIU, K. M. CHU*

Department of Surgery, The University of Hong Kong, Queen Mary Hospital, Hong Kong

*Correspondence: chukm@hku.hk

Received May 11, 2015 / Accepted July 29, 2015

\begin{abstract}
Early diagnosis of gastric cancer is critical to decrease the mortality of this globally fatal disease. Currently, endoscopic biopsy is the gold standard for diagnosis of gastric cancer. However, invasiveness and high expense limit its application. Hence, non-invasive and cost-effective biomarkers for early detection and subsequent management are crucial steps to monitor gastric cancer. Recent studies suggest that circulating cell-free nucleic acids, including circulating tumor DNAs and microRNAs (miRNAs), are promising for various applications. Development of such blood-based biomarkers is expected to facilitate detection, predict prognosis, monitor chemotherapeutic response and manage recurrence of human cancers. In this review, the characteristics of circulating cell-free DNAs and miRNAs will be elucidated, including their origin and dysregulation. Mutations and hypermethylation of circulating DNAs, abnormal alternations of expression of circulating miRNAs will be revealed as aberrant changes indicating gastric cancer. The roles of circulating DNAs and miRNAs for early detection of gastric cancer will be focused on, as well as the challenges of developing circulating nucleic acids as biomarkers.
\end{abstract}

Key words: circulating DNA, circulating miRNA, biomarker, gastric cancer, early detection

\section{Epidemiology and diagnosis of gastric cancer}

Gastric cancer is the fourth commonest cancer and the second leading cause of cancer associated death worldwide $[1,2]$. More than 70\% of gastric cancer cases occur in eastern Asia [2]. This is mainly attributed to the high frequency of Helicobacter Pylori (H. Pylori) infection, salty and preserved dietary, as well as large number of smoking population in eastern Asians [3]. Currently, complete surgical resection is the most effective therapy for patients with early gastric cancer, offering an excellent survival rate of more than 90\% [4]. However, the majority of patients with gastric cancer are diagnosed at an advanced stage, resulting in the average 5-year survival rate around $20-25 \%$ [5]. The dramatic difference indicates the critical influence of early detection of gastric cancer on its prognosis. However, the symptoms of gastric cancer at the early stage, such as uncomfortable in the upper abdomen, belching, early satiety, etc. are atypical and subjective. As there is no standard assay for screening or early detection of gastric cancer, most of the patients go for medical examination until they are at an advanced stage $[6,7]$. This situation makes it urgent to develop a method for early detection of gastric cancer.

As H. Pylori infection is the strongest known risk factor for gastric cancer, people with persistent $H$. Pylori infection, especially those with chronic atrophic gastritis are highly recommended to take surveillance by regular examination [8]. Currently, the most reliable diagnosis of gastric cancer is biopsy [9]. The observation of gastric mucosa under endoscopy and the histological evaluation of gastric tissue taken from endoscopy make the final decision of gastric cancer [10]. However, biopsy requires experts with intensive training to operate endoscopy and pathologists with experience to examine the mucosa, as well as the purchase and maintenance of the equipment. These conditions may not be available in some developing countries or remote regions. Besides, biopsy is not applicable for some patients refusing such invasive ex- 
amination [11]. Moreover, biopsy is taken just once, making it not practical for repeated sampling for cancer monitoring. Therefore, a non-invasive, cost-effective and patient-friendly application for early detection of gastric cancer and the follow up tracing of therapy is necessary and urgent.

\section{Current blood-based biomarkers for detection of gastric cancer}

Biomarkers refer to molecules or substances found in blood, other bodily fluids or tissues that reflect a particular biological or pathological state. Blood-based biomarkers are ideal application for cancer diagnostics. Biomarkers from blood provide a non-invasive, cost-effective and patientfriendly assay for detection of gastric cancer. It is promising to revolutionize gastric cancer diagnostics. Carcinoembryonic antigen (CEA), carbohydrate antigen 19-9 (CA 19-9) and carbohydrate antigen 72-4 (CA 72-4) [12, 13], or pepsinogen I /II ratio (PGI/II) $[14,15]$ they all are common blood-based biomarkers for risk screening of gastric cancer. However, the sensitivity and specificity of these biomarkers are just around $30-50 \%[16,17]$, much less than satisfactory for accurate detection of gastric cancer. Besides the biochemical biomarkers, it has been proposed that circulating tumor cells (CTCs) are alterative biomarkers for cancer detection and monitoring [18, 19]. But this requires physically separating multiple kinds of cells in blood to accumulate circulating tumor cells. This is difficult as around 1-10 CTCs together with several million blood cells could be found in $1 \mathrm{ml}$ of whole blood [20]. And the epithelial markers to characterize CTCs are downregulated during tumor cell dissemination in certain tumor types. Until now, there are no standard criteria to differentiate tumor cells from other kinds of cells in blood [21, 22]. Hence, a brand new biomarker with high sensitivity and specificity, as well as non-invasiveness is urgent in need.

\section{Circulating nucleic acids for cancer detection and management}

In recent years, a new kind of biomarkers, circulating cell-free nucleic acids (cfNAs), attracts lots of attention. Circulating cell-free tumor-associated nucleic acids are thought to be released into the blood through apoptosis, necrosis or secretion from cancer cells in the tumor microenvironment $[23,24]$. Macrophages may also play an important role in generating circulating cell-free nucleic acids [25]. The amount of circulating cfNAs is influenced by the tumor size and the rate of their clearance [26-28]. As the quantification of cfDNA concentrations overlap between healthy individuals and patients with benign and malignant disease $[29,30]$, it is necessary to assess quantitative cfNAs in large cohorts of patients with well-defined clinical parameters. But the remaining high level of cfDNA of the same patient might indicate the presence of residual tumor cells or micro-metastasis in the tumor microenvironment [31].
On the other hand, it has been reported that circulating cfDNAs contain the aberrant genetic or epigenetic alterations that represent their original cancer, even at the early stage of cancer development $[32,33]$. This evidence provides the base of early detection of cancer using circulating cfDNAs. Circulating cfDNAs contain tumor mutations or abnormal DNA methylation that is unique to the patient $[34,35]$. The amount of circulating tumor-derived miRNAs also provides the hints to tumor occurrence and progression [36]. This provides evidence to apply circulating cfNAs as "liquid biopsy" in clinic. This application is quite meaningful as it is convenient to provide sensitive and specific serial sampling during the course of disease, considering that avoiding repeated biopsy. Convenience of serial sampling also facilitates cancer management and monitoring, such as, therapy response prediction, disease prognostics and recurrence in patients $[33,37,38]$. For example, it has been demonstrated that detection of mutations in circulating tumor DNAs correlated with responses to chemotherapy and metastasis of breast cancer [39].

\section{Circulating cell-free DNAs for early detection of gastric cancer}

Circulating DNAs with gene mutations. High frequency of gene mutations contained in circulating cell-free DNAs (cfDNAs) provides evidence to assess the tumor occurrence and progression. A patient's tumor contains large chromosomal rearrangements that were unique to that patient, which could be picked out by polymerase chain reaction (PCR) [32]. The amount of blood-based tumor DNA with specific mutations could be tracked for cancer detection and could be applied to monitor the patient's response to treatments. Genes such as KRAS and TP53 are with high frequency of mutations in various human cancers [40-42]. But these genes are not specific to gastric cancer. They may combine with other mutations more specific to gastric cancer for its early detection. Hence, identification of oncogenes or tumor suppressor genes with frequent mutations in gastric cancer is the premise of such application.

It has been reported that germ-line epithelial cadherin (CDH1) contains mutations in $25 \%$ to $40 \%$ of the hereditary diffuse gastric cancer (HDGC) [43, 44]. CDH1 mutation is very important considering it harbors relative high frequency of gene mutations in gastric cancer, especially in the low-risk areas [45]. Recently, novel $\mathrm{CDH} 1$ mutations have been identified in sporadic Chinese gastric cancer patients, providing new evidence for screening and early detection of gastric cancer in the high risk areas [46]. Besides $C D H 1$, high frequency of mutations of the PIK3CA (phosphatidylinositol 3-kinase) gene in the helical domain and kinase domain has been reported in various human cancers, including gastric cancer [47]. The mutation frequency varies up to $25 \%$ in gastric adenocarcinoma $[48,49]$, higher than other genes examined [50]. Recently, it has been revealed that mutations in ARID1A (AT rich interactive domain $1 \mathrm{~A}$ ) are associated with 
concurrent PIK3CA mutations and microsatellite instability in gastric adenocarcinoma [51]. This may provide more accurate detection by analysis of the concurrent mutations of PIK3CA and ARID1A in the circulation of gastric cancer candidates. Besides the genes aforementioned, mutations in genes such as EGFR [52, 53] and PTEN [54, 55] have also been reported in gastric cancer, providing potential circulating DNAs for detection of gastric cancer.

The leading challenge of mutation assays in cfDNA is the mutations might be diluted by wild-type DNA in the blood, making them as relative low frequency mutations occurring in gastric cancer. Moreover, not all of the tumors that carry DNA mutations can be detected in the blood. Though the detection of gene mutations aforementioned provides promising potential circulating cfDNAs for early diagnosis of gastric cancer, identification of oncogenes or tumor suppressor genes with high frequency of mutations specific to gastric cancer is undergoing. This is critical for its clinical application in bloodbased detection of gastric cancer.

Circulating DNAs with hypermethylation. Besides mutations, aberrant alterations of methylation status in circulating cfDNAs released from gastric cancer cells are also promising biomarkers for risk assessment of gastric cancer. Promoter hypermethylation of tumor suppressor genes, such as p16, has been found to be more frequently responsible for the silence of them than mutations in sporadic gastric cancer [56]. Although epigenetic alterations are not unique for a single tumor type, there are particular tumor suppressor genes that are frequently methylated and downregulated in certain tumors [57-59]. Indeed, abnormal DNA methylation was detected in plasma samples of cancer patients. For example, it was revealed that detection of circulating methylated RASSF1A (Ras association domain family 1) by fluorescent-based methylation specific PCR (MS-PCR) in melanoma patients [60]. For digestive tract tumors, the development of detection of methylated SEPT9 (septin9) in early colorectal cancer (CRC) by real-time PCR in plasma samples is undergoing $[35,61]$. This demonstrates the potential utility of diagnostic screening of methylated tumorrelated cfDNA in population to identify the tumor type.

For gastric cancer, it was shown that methylation of TFPI2 (tissue factor pathway inhibitor-2) can be detected in the serum of gastric cancer patients by quantitative methylation specific-PCR (q-MSP) [62]. Another paper demonstrated that cumulated methylated RUNX3 (runt-related transcription factor 3) in serum samples was associated with gastric cancer initiation, progression and disease-free survival [63]. In addition to these, other studies indicated that significantly different frequencies of methylation status in genes were observed in circulation between early gastric cancer and non-cancer subjects [64]. For example, high frequency of methylation was found in RPRM and RNF180 in plasma samples [65,66], as well as in $p 15, D A P K$ and SFRP2 in serum samples of patients with gastric cancer $[67,68]$. Such evidence indicates the potential application of circulating methylated cfDNAs for detection of gastric cancer (Table1).
Table1. Circulating methylated DNAs for detection of gastric cancer.

\begin{tabular}{|c|c|c|c|}
\hline Genes & Serum/Plasma & Methylation Frequency & References \\
\hline p16 & Serum & $\begin{array}{l}14 \text { out of } 52 \text { patients } \\
0 \text { out of } 50 \text { controls }\end{array}$ & [56] \\
\hline TFPI2 & Serum & $\begin{array}{l}7 \text { out of } 73 \text { patients } \\
0 \text { out of } 20 \text { controls }\end{array}$ & {$[62]$} \\
\hline RUNX3 & Serum & $\begin{array}{l}143 \text { out of } 202 \text { patients } \\
2 \text { out of } 854 \text { controls }\end{array}$ & {$[63]$} \\
\hline RPRM & Plasma & $\begin{array}{l}41 \text { out of } 43 \text { patients } \\
3 \text { out of } 31 \text { controls }\end{array}$ & [65] \\
\hline RNF180 & Plasma & $\begin{array}{l}18 \text { out of } 32 \text { patients } \\
0 \text { out of } 64 \text { patients }\end{array}$ & [66] \\
\hline p15 & Serum & $\begin{array}{l}30 \text { out of } 54 \text { patients } \\
0 \text { out of } 30 \text { controls }\end{array}$ & [67] \\
\hline DAPK & Serum & $\begin{array}{l}26 \text { out of } 54 \text { patients } \\
0 \text { out of } 30 \text { controls }\end{array}$ & [67] \\
\hline SFRP2 & Serum & $\begin{array}{l}12 \text { out of } 18 \text { patients } \\
0 \text { out of } 18 \text { controls }\end{array}$ & {$[68]$} \\
\hline
\end{tabular}

The application of this approach depends on the identification of tumor suppressor genes (TSGs) that are frequently methylated and downregulated in early stage of gastric cancer, as well as the accurate technique of detection of DNA methylation status in serum or plasma samples. To identify such TSGs, previous studies indicated that promoter hypermethylation of $p 16$ and DAPK (Death-associated protein kinase) genes might play an important role in the pathogenesis of gastric epithelial dysplasia and early gastric adenocarcinoma $[69,70]$. Moreover, there was a significant association between hypermethylation of $p 16$ and MGMT (O-6-methylguanine-DNA methyltransferase) and elevated serum CEA level [70]. This evidence provides genes with DNA hypermethylation specific to gastric cancer. And the hypermethylation in these genes may be combined with other blood-based biomarkers (such as CEA) for more accurate early detection of gastric cancer. Besides p16 and DAPK, other genes with DNA hypermethylation in gastric cancer tissue samples was revealed, such as TSLC1 (cell adhesion molecule 1) and DCC (Deleted in colorectal carcinoma) $[71,72]$. These events are clinically promising, as they demonstrate that blood-based samples obtained in population or clinic can be applied for estimating cancer risk or early detection of gastric cancer.

\section{Circulating miRNAs for early detection of gastric cancer}

Other than circulating cfDNAs, circulating miRNAs is another group of promising biomarkers for early detection of cancer due to a strong link between the dysregulation of miRNAs and cancer initiation and progression [73-75]. The discovery of miRNAs in plasma or serum provides the potential of applying them as non-invasive biomarkers in cancer detection and as predictors of response to chemotherapy [76]. In addition to their high stability in circulation, the 
characteristics of miRNAs such as tissue-specific signatures and the availability of many copies per cell indicate their potential advantages as biomarkers. It was firstly reported that upregulation of circulating miRNAs was an indicator for diffuse large B cell lymphoma [77]. Later, dysregulation of circulating miRNAs was revealed in other cancer types, including breast cancer, colorectal cancer and liver cancer [78-80].

For gastric cancer, dysregulation of miRNAs was demonstrated by miRNA expression profiling between non-tumor mucosa and cancer samples [81]. This evidence indicates that unique miRNAs are associated with development of gastric cancer, providing the possibility of circulating miRNAs for gastric cancer detection and monitoring. Actually, aberrant amount of miRNAs have been detected in both serum and plasma samples from gastric cancer patients [82]. Dysregulation of circulating miRNAs for detection of gastric cancer was first revealed in 2010. Two studies indicated that miRNA signatures in plasma or serum could be applied as novel biomarkers for diagnosis of gastric cancer $[83,84]$. Since then, a number of studies showed that circulating miRNAs were promising biomarkers for early detection of gastric cancer. For example, it was revealed that elevated serum level of miR-378 can be applied as a biomarker for early detection of gastric cancer, with an AUC of 0.861 [85]. Another paper suggested that circulating miR-223 $(P<0.001)$ and miR-21 $(P<0.001)$ were significantly higher in the plasma of gastric cancer patients than in healthy controls, while miR-218 $(P<0.001)$ was significantly lower. The ROC analysis of the ratio of (miR-223 X miR-21)/miR-218 indicated an AUC value of 0.9531 , which could discriminate GC patients from healthy controls [86]. As there are two types of gastric cancer, intestinal type and diffuse type, with different biological behaviors [87], a recent study focusing on diffuse-type gastric cancer (DGC) demonstrated a combination of four upregulated miRNAs (miR-103, miR-107, miR-194 and miR-210) in serum as biomarkers for early detection of DGC using a mouse model. With cut-off levels released by ROC curve analyses, the overall sensitivity and specificity of the miRNAs were $>80 \%$ and $>90 \%$ separately [88]. Dysregulation of circulating miRNAs as biomarkers for detection of gastric cancer was summarized in Table2 [89-91].

The evidence of aforementioned suggests a promising application of detection of gastric cancer using blood-based samples. However, there are discrepancies of the upregulation of circulating miRNAs from the same tumor type in different studies [92]. This is mainly attributed to the relative small sample size $(\mathrm{N}<100)$ and lack of a well-established endogenous miRNA control to normalize miRNA amounts. Even frequently used reference miRNAs (such as RNU6 and 5S) are variable under different physiological conditions or patient and donor demographics [36]. It was released that several miRNAs could be used as internal controls in plasma or serum samples [93-95]. But the universal standards of internal control of miRNAs to provide a better normalization of miRNA in plasma or serum are still under development. This approach also strongly requires the internal control miRNAs to be well studied in relevant defined populations

Table2. Circulating miRNAs for detection of gastric cancer.

\begin{tabular}{|c|c|c|c|c|}
\hline miRNAs & $\begin{array}{l}\text { Cancer Type } \\
\text { (Intestinal/Diffuse) }\end{array}$ & Serum/Plasma & Sensitivity/Specificity & References \\
\hline $\begin{array}{l}\text { miR-17-5p, miR-21, miR-106a, miR-106b, } \\
\text { (let-7a) }\end{array}$ & Both Types & Plasma & $\begin{array}{l}85.5 \% / 80.0 \% \text { for } \\
\text { miR106b/let7a } \\
\text { (optical value) }\end{array}$ & [83] \\
\hline $\begin{array}{l}\text { miR-1, miR-20a, } \\
\text { miR-27a, miR-34, miR-423-5p }\end{array}$ & Both Types & Serum & $\begin{array}{l}88 \% / 77 \% \text { of Set } 1 \\
81 \% / 71 \% \text { of Set } 2 \\
\text { (Value of combined } \\
\text { five miRNAs) }\end{array}$ & {$[84]$} \\
\hline $\operatorname{miR}-378$ & Both Types & Serum & $87.5 \% / 70.7 \%$ & [85] \\
\hline miR-223, miR-21, (miR-218) & Both Types & Plasma & $\begin{array}{l}84.29 \% / 92.86 \% \text { for } \\
\left(\mathrm{miR}-223^{*} \mathrm{miR} 21\right) / \mathrm{miR} 218\end{array}$ & [86] \\
\hline miR-103, miR-107, miR-194, miR-210 & $\begin{array}{l}\text { Diffuse Type } \\
\text { (mouse model) }\end{array}$ & Serum & $\begin{array}{l}81.8 \% / 95.7 \% \text { for miR-103 } \\
90.9 \% / 95.7 \% \text { for miR-107 } \\
90.9 \% / 95.7 \% \text { for miR-194 } \\
72.7 \% / 87.0 \% \text { for miR-210 }\end{array}$ & [88] \\
\hline miR-451, miR-486 & Both Types & Plasma & $\begin{array}{l}96 \% / 100 \% \text { for miR- } 451 \\
86 \% / 97 \% \text { for miR- } 486\end{array}$ & [89] \\
\hline miR-221, miR-744, miR-376c & $\begin{array}{l}\text { Both Types } \\
\text { (Dysplasia samples) }\end{array}$ & Serum & $\begin{array}{l}82.4 \% / 58.8 \% \text { for GC } \\
56.5 \% / 47.8 \% \text { for Dysplasia } \\
\text { (Value of combined } \\
\text { three miRNAs) }\end{array}$ & {$[90]$} \\
\hline miR-199a-3p & Both Types & Plasma & $80 \% / 74 \%$ & [91] \\
\hline
\end{tabular}

( ) indicates downregulation of miRNAs in circulation for detection of gastric cancer, while other miRNAs are upregulated ones. 
[92]. Another crucial aspect is the extraction of miRNAs from plasma or serum samples. It should minimize the variation of the amount of miRNAs from one sample to another, as they are of small size and protected by lipids and proteins [69].

\section{Conclusions and future perspectives}

Early detection of gastric cancer is essential to decrease the mortality of this global lethal disease. Histological evaluation of gastric mucosa obtained from endoscopy is the "golden standard" of diagnosis $[9,10]$. But sometimes it is not easy for patients in certain conditions or in regions lack of the experts or equipment. Routine screening and clinical application require easily implementable tests for biomarker analyses. Some serum biomarkers such as CEA and CA19-9 are not sensitive or specific enough to satisfy early detection of gastric cancer [3]. Thus, it is urgent to search for other blood-based tumor biomarkers for gastric cancer diagnosis. In this review, it has been demonstrated the emerging roles of circulating cell-free nucleic acids (cfDNAs and miRNAs) as novel non-invasive biomarkers for early detection of gastric cancer. Circulating cfDNAs with certain mutations or hypermethylation, or dysregulation of circulating miRNAs may also be useful biomarkers to help the doctors decide whether to apply prompt endoscopy to the patients. For example, endoscopy should be applied for dyspeptic patients with high level of circulating miRNAs or mutated DNAs, especially in regions with a high risk of gastric cancer.

The main challenge in evaluating cfNAs is the standardization of assays, such as DNA or miRNA extraction, internal controls, assay conditions, sensitivity and specificity [28]. It also remains controversial whether plasma or serum is the optimal sampling specimen, considering that the coagulation process may affect the spectrum of extracellular miRNA in blood [62]. To summarize, advantages and limitations of various biomarkers mentioned above were listed in Table3. To overcome the limitations, improvements in methodologies are undergoing. For instance, the development of a direct DNA assay without extraction may overcome many of these problems [96]. New approaches in the assessment of cfDNA are being developed to validate gene mutations or methylation status in circulating cfDNAs, such as cfDNA next generation sequencing (NGS). NGS is a brand new technology for faster and lower-cost sequencing to determine DNA sequence [97]. The advantage of NGS is to perform sequencing of millions of fragments of DNA from a single sample simultaneously. Application of such massively parallel sequencing technology facilitates the discovery of mutations in the blood samples, with less time, cost and personnel [98]. This technology is also promising in application for gastric cancer [99]. For circulating miRNA, the universal standard of miRNAs for normalization of miRNA amount is also in need. Although problems remain to be solved, such minimally invasive blood-based cell-free DNA and miRNA
Table3. Advantages and limitations of biomarkers

\begin{tabular}{|c|c|c|}
\hline Biomarkers & Advantages & Limitations \\
\hline $\begin{array}{l}\text { Biochemical } \\
\text { Biomarkers (such as } \\
\text { CEA and CA19-9) }\end{array}$ & $\begin{array}{l}\text { Easy to detect, } \\
\text { Cost-effective }\end{array}$ & $\begin{array}{l}\text { Low sensitivity, } \\
\text { Low specificity. }\end{array}$ \\
\hline $\begin{array}{l}\text { CTCs } \\
\text { (Circulating Tumor } \\
\text { Cells) }\end{array}$ & Specific for GC & $\begin{array}{l}\text { Difficult to separate, } \\
\text { Be diluted in tumor } \\
\text { cell dissemination. }\end{array}$ \\
\hline $\begin{array}{l}\text { Circulating Mutated } \\
\text { DNAs }\end{array}$ & $\begin{array}{l}\text { Early stage of GC, } \\
\text { High specificity }\end{array}$ & $\begin{array}{l}\text { Influence by tumor size } \\
\text { and the rate of clearance, } \\
\text { Relatively low frequency, } \\
\text { Standard of DNA extraction. }\end{array}$ \\
\hline $\begin{array}{l}\text { Circulating } \\
\text { Methylated DNAs }\end{array}$ & $\begin{array}{l}\text { Early stage of GC, } \\
\text { High sensitivity, } \\
\text { Easy to detect }\end{array}$ & $\begin{array}{l}\text { Influence by tumor size } \\
\text { and the rate of clearance, } \\
\text { Selection of methylation of GC, } \\
\text { Standard of DNA extraction. }\end{array}$ \\
\hline Circulating miRNAs & $\begin{array}{l}\text { Early stage of GC, } \\
\text { Easy to detect, } \\
\text { High sensitivity, } \\
\text { High specificity }\end{array}$ & $\begin{array}{l}\text { Standard of miRNA extraction, } \\
\text { Selection of internal control, } \\
\text { Use of Plasma or Serum. }\end{array}$ \\
\hline
\end{tabular}

are promising to complement or replace the existing cancer tissue and blood biomarkers in the future.

\section{References}

[1] SIEGEL R, NAISHADHAM D, JEMAL A: Cancer statistics, 2013. CA Cancer J Clin 2013, 63: 11-30. http://dx.doi. org/10.3322/caac.21166

[2] JEMAL A, BRAY F, CENTER MM, FERLAY J, WARD E, et al: Global cancer statistics. CA Cancer J Clin 2011, 61: 69-90. http://dx.doi.org/10.3322/caac.20107

[3] LEUNG WK, WU MS, KAKUGAWA Y, KIM JJ, YEOH KG, et al: Screening for gastric cancer in Asia: current evidence and practice. Lancet Oncol 2008, 9: 279-287. http://dx.doi. org/10.1016/S1470-2045(08)70072-X

[4] DINIS-RIBEIRO M, AREIA M, DE VRIES AC, MARCOSPINTO R, MONTEIRO-SOARES M, et al: Management of precancerous conditions and lesions in the stomach (MAPS): guideline from the European Society of Gastrointestinal Endoscopy (ESGE), European Helicobacter Study Group (EHSG), European Society of Pathology (ESP), and the Sociedade Portuguesa de Endoscopia Digestiva (SPED). Virchows Arch 2012, 460: 19-46. http://dx.doi.org/10.1007/s00428-011$\underline{1177-8}$

[5] CARPELAN-HOLMSTROM M, LOUHIMO J, STENMAN UH, ALFTHAN H, HAGLUND C: CEA, CA 19-9 and CA 72-4 improve the diagnostic accuracy in gastrointestinal cancers. Anticancer Res 2002, 22: 2311-2316.

[6] KHUSHALANI N: Cancer of the esophagus and stomach. Mayo Clin Proc 2008, 83: 712-722. http://dx.doi.org/10.1016/ S0025-6196(11)60900-2

[7] WESOLOWSKI R, LEE C, KIM R: Is there a role for second-line chemotherapy in advanced gastric cancer? Lancet Oncol 2009, 10: 903-912. http://dx.doi.org/10.1016/S14702045(09)70136-6 
[8] GONZALEZ CA, AGUDO A: Carcinogenesis, prevention and early detection of gastric cancer: where we are and where we should go. Int J Cancer 2012, 130: 745-753. http://dx.doi. org/10.1002/ijc. 26430

[9] LEAKE PA, CARDOSO R, SEEVARATNAM R, LOURENCO L, HELYER L, et al: A systematic review of the accuracy and indications for diagnostic laparoscopy prior to curativeintent resection of gastric cancer. Gastric Cancer 2012, 15 Suppl 1: S38-47. http://dx.doi.org/10.1007/s10120-011$\underline{0047-z}$

[10] HORI Y: DIAGNOSTIC LAPAROSCOPY GUIDELINES : This guideline was prepared by the SAGES Guidelines Committee and reviewed and approved by the Board of Governors of the Society of American Gastrointestinal and Endoscopic Surgeons (SAGES), November 2007. Surg Endosc 2008, 22: 1353-1383. http://dx.doi.org/10.1007/s00464-008-9759-5

[11] EL ABIAD R, GERKE H: Gastric cancer: endoscopic diagnosis and staging. Surg Oncol Clin N Am 2012, 21: 1-19. http://dx.doi.org/10.1016/j.soc.2011.09.002

[12] MARRELLI D, PINTO E, DE STEFANO A, FARNETANI M, GAROSI L, et al: Clinical utility of CEA, CA 19-9, and CA 72-4 in the follow-up of patients with resectable gastric cancer. Am J Surg 2001, 181: 16-19. http://dx.doi.org/10.1016/ S0002-9610(00)00549-3

[13] YCHOU M, DUFFOUR J, KRAMAR A, GOURGOU S, GRENIER J: Clinical significance and prognostic value of CA72-4 compared with CEA and CA19-9 in patients with gastric cancer. Dis Markers 2000, 16: 105-110. http://dx.doi. org/10.1155/2000/595492

[14] BROUTET N, PLEBANI M, SAKAROVITCH C, SIPPONEN P, MEGRAUD F: Pepsinogen A, pepsinogen C, and gastrin as markers of atrophic chronic gastritis in European dyspeptics. Br J Cancer 2003, 88: 1239-1247. http://dx.doi.org/10.1038/ sj.bjc. 6600877

[15] MIKI K: Gastric cancer screening using the serum pepsinogen test method. Gastric Cancer 2006, 9: 245-253. http://dx.doi. org/10.1007/s10120-006-0397-0

[16] SCHNEIDER J, SCHULZE G: Comparison of tumor M2pyruvate kinase (tumor M2-PK), carcinoembryonic antigen (CEA), carbohydrate antigens CA 19-9 and CA 72-4 in the diagnosis of gastrointestinal cancer. Anticancer Res 2003, 23: 5089-5093.

[17] LAMBERT R, SAITO H, LUCAS E, SANKARANARAYANAN R: Survival from digestive cancer in emerging countries in Asia and Africa. Eur J Gastroenterol Hepatol 2012, 24: 605-612. http://dx.doi.org/10.1097/ MEG.0b013e328351e39d

[18] NAGRATH S, SEQUIST LV, MAHESWARAN S, BELL DW, IRIMIA D, et al: Isolation of rare circulating tumour cells in cancer patients by microchip technology. Nature 2007, 450: 1235-1239. http://dx.doi.org/10.1038/nature06385

[19] PUNNOOSE EA, ATWAL SK, SPOERKE JM, SAVAGE H, PANDITA A, et al: Molecular biomarker analyses using circulating tumor cells. PLoS One 2010, 5: e12517. http://dx.doi. org/10.1371/journal.pone.0012517

[20] MOCELLIN S, KEILHOLZ U, ROSSI CR, NITTI D: Circulating tumor cells: the ,leukemic phase' of solid cancers. Trends
Mol Med 2006, 12: 130-139. http://dx.doi.org/10.1016/j. molmed.2006.01.006

[21] DANILA DC, PANTEL K, FLEISHER M, SCHER HI: Circulating tumors cells as biomarkers: progress toward biomarker qualification. Cancer J 2011, 17: 438-450. http:// dx.doi.org/10.1097/PPO.0b013e31823e69ac

[22] JOOSSE SA, PANTEL K: Biologic challenges in the detection of circulating tumor cells. Cancer Res 2013, 73: 8-11. http:// dx.doi.org/10.1158/0008-5472.CAN-12-3422

[23] JAHR S, HENTZE H, ENGLISCH S, HARDT D, FACKELMAYER FO, et al: DNA fragments in the blood plasma of cancer patients: quantitations and evidence for their origin from apoptotic and necrotic cells. Cancer Res 2001, 61: 1659-1665.

[24] GAHAN PB, SWAMINATHAN R: Circulating nucleic acids in plasma and serum. Recent developments. Ann N Y Acad Sci 2008, 1137: 1-6. http://dx.doi.org/10.1196/annals. 1448.050

[25] CHOI JJ, REICH CF, 3RD, PISETSKY DS: The role of macrophages in the in vitro generation of extracellular DNA from apoptotic and necrotic cells. Immunology 2005, 115: 55-62. http://dx.doi.org/10.1111/j.1365-2567.2005.02130.x

[26] BENDICH A, WILCZOK T, BORENFREUND E: CIRCULATING DNA AS A POSSIBLE FACTOR IN ONCOGENESIS. Science 1965, 148: 374-376. http://dx.doi. org/10.1126/science.148.3668.374

[27] DIEHL F, LI M, DRESSMAN D, HE Y, SHEN D, et al: Detection and quantification of mutations in the plasma of patients with colorectal tumors. Proc Natl Acad Sci U S A 2005, 102: 16368-16373. http://dx.doi.org/10.1073/ pnas.0507904102

[28] FLEISCHHACKER M, SCHMIDT B: Circulating nucleic acids (CNAs) and cancer--a survey. Biochim Biophys Acta 2007, 1775: 181-232.

[29] BODDY JL, GAL S, MALONE PR, HARRIS AL, WAINSCOAT JS: Prospective study of quantitation of plasma DNA levels in the diagnosis of malignant versus benign prostate disease. Clin Cancer Res 2005, 11: 1394-1399. http://dx.doi. org/10.1158/1078-0432.CCR-04-1237

[30] KAMAT AA, BALDWIN M, URBAUER D, DANG D, HAN LY, et al: Plasma cell-free DNA in ovarian cancer: an independent prognostic biomarker. Cancer 2010, 116: 1918-1925. http://dx.doi.org/10.1002/cncr.24997

[31] WIMBERGER P, ROTH C, PANTEL K, KASIMIR-BAUER S, KIMMIG R, et al: Impact of platinum-based chemotherapy on circulating nucleic acid levels, protease activities in blood and disseminated tumor cells in bone marrow of ovarian cancer patients. Int J Cancer 2011, 128: 2572-2580. http://dx.doi. org/10.1002/ijc. 25602

[32] SCHWARZENBACH H, HOON DS, PANTEL K: Cell-free nucleic acids as biomarkers in cancer patients. Nat Rev Cancer 2011, 11: 426-437. http://dx.doi.org/10.1038/nrc3066

[33] SHINOZAKI M, O'DAY SJ, KITAGO M, AMERSI F, KUO C, et al: Utility of circulating B-RAF DNA mutation in serum for monitoring melanoma patients receiving biochemotherapy. Clin Cancer Res 2007, 13: 2068-2074. http://dx.doi. org/10.1158/1078-0432.CCR-06-2120 
[34] DAWSON SJ, TSUI DW, MURTAZA M, BIGGS H, RUEDA $\mathrm{OM}$, et al: Analysis of circulating tumor DNA to monitor metastatic breast cancer. N Engl J Med 2013, 368(: 1199-1209.

[35] PAYNE SR: From discovery to the clinic: the novel DNA methylation biomarker $(\mathrm{m})$ SEPT9 for the detection of colorectal cancer in blood. Epigenomics 2010, 2: 575-585. http:// dx.doi.org/10.2217/epi.10.35

[36] MITCHELL PS, PARKIN RK, KROH EM, FRITZ BR, WYMAN SK, et al: Circulating microRNAs as stable bloodbased markers for cancer detection. Proc Natl Acad Sci U S A 2008, 105: 10513-10518. http://dx.doi.org/10.1073/ pnas.0804549105

[37] SOZZI G, CONTE D, MARIANI L, LO VULLO S, ROZ L, et al: Analysis of circulating tumor DNA in plasma at diagnosis and during follow-up of lung cancer patients. Cancer Res 2001, 61: 4675-4678.

[38] DIEHL F, SCHMIDT K, CHOTI MA, ROMANS K, GOODMAN S, et al: Circulating mutant DNA to assess tumor dynamics. Nat Med 2008, 14: 985-990. http://dx.doi. org/10.1038/nm.1789

[39] LIPPMAN M, OSBORNE CK: Circulating tumor DNA-ready for prime time? N Engl J Med 2013, 368: 1249-1250. http:// dx.doi.org/10.1056/NEJMe1301249

[40] YAMAGUCHI F, KUGAWA S, TATENO H, KOKUBU F, FUKUCHI K: Analysis of EGFR, KRAS and P53 mutations in lung cancer using cells in the curette lavage fluid obtained by bronchoscopy. Lung Cancer 2012, 78: 201-206. http://dx.doi. org/10.1016/j.lungcan.2012.08.014

[41] GARCIA-DIOS DA, LAMBRECHTS D, COENEGRACHTS L, VANDENPUT I, CAPOEN A, et al: High-throughput interrogation of PIK3CA, PTEN, KRAS, FBXW7 and TP53 mutations in primary endometrial carcinoma. Gynecol Oncol 2013, 128: 327-334. http://dx.doi.org/10.1016/j. ygyno.2012.11.037

[42] RECHSTEINER M, VON TEICHMAN A, RUSCHOFF JH, FANKHAUSER N, PESTALOZZI B, et al: KRAS, BRAF, and TP53 Deep Sequencing for Colorectal Carcinoma Patient Diagnostics. J Mol Diagn 2013, 15: 299-311. http://dx.doi. org/10.1016/j.jmoldx.2013.02.001

[43] FITZGERALD RC, CALDAS C: Clinical implications of E-cadherin associated hereditary diffuse gastric cancer. Gut 2004, 53: 775-778. http://dx.doi.org/10.1136/ gut.2003.022061

[44] KAURAH P, MACMILLAN A, BOYD N, SENZ J, DE LUCA A, et al: Founder and recurrent CDH1 mutations in families with hereditary diffuse gastric cancer. JAMA 2007, 297: 2360-2372. http://dx.doi.org/10.1001/ jama.297.21.2360

[45] CORSO G, MARRELLI D, PASCALE V, VINDIGNI C, ROVIELLO F: Frequency of CDH1 germline mutations in gastric carcinoma coming from high- and low-risk areas: metanalysis and systematic review of the literature. BMC Cancer 2012, 12: 8. http://dx.doi.org/10.1186/1471-2407-12-8

[46] CHEN QH, DENG W, LI XW, LIU XF, WANG JM, et al: Novel CDH1 germline mutations identified in Chinese gastric cancer patients. World J Gastroenterol 2013, 19: 909-916. http://dx.doi.org/10.3748/wjg.v19.i6.909
[47] SAMUELS Y, WANG Z, BARDELLI A, SILLIMAN N, PTAK J, et al: High frequency of mutations of the PIK3CA gene in human cancers. Science 2004, 304: 554. http://dx.doi. org/10.1126/science. 1096502

[48] LI VS, WONG CW, CHAN TL, CHAN AS, ZHAO W, et al: Mutations of PIK3CA in gastric adenocarcinoma. BMC Cancer 2005, 5: 29. http://dx.doi.org/10.1186/1471-2407-5-29

[49] VELHO S, OLIVEIRA C, FERREIRA A, FERREIRA AC, SURIANO G, et al: The prevalence of PIK3CA mutations in gastric and colon cancer. Eur J Cancer 2005, 41: 1649-1654. http://dx.doi.org/10.1016/j.ejca.2005.04.022

[50] LEE J, VAN HUMMELEN P, GO C, PALESCANDOLO E, JANG J, et al: High-throughput mutation profiling identifies frequent somatic mutations in advanced gastric adenocarcinoma. PLoS One 2012, 7: e38892. http://dx.doi.org/10.1371/ journal.pone.0038892

[51] ZANG ZJ, CUTCUTACHE I, POON SL, ZHANG SL, MCPHERSON JR, et al: Exome sequencing of gastric adenocarcinoma identifies recurrent somatic mutations in cell adhesion and chromatin remodeling genes. Nat Genet 2012, 44: 570-574. http://dx.doi.org/10.1038/ng.2246

[52] CORSO G, VELHO S, PAREDES J, PEDRAZZANI C, MARTINS D, et al: Oncogenic mutations in gastric cancer with microsatellite instability. Eur J Cancer 2011, 47: 443-451. http://dx.doi.org/10.1016/j.ejca.2010.09.008

[53] LIU Z, LIU L, LI M, WANG Z, FENG L, et al: Epidermal growth factor receptor mutation in gastric cancer. Pathology 2011, 43: 234-238. http://dx.doi.org/10.1097/ PAT.0b013e328344e61b

[54] WEN YG, WANG Q, ZHOU CZ, QIU GQ, PENG ZH, et al: Mutation analysis of tumor suppressor gene PTEN in patients with gastric carcinomas and its impact on PI3K/AKT pathway. Oncol Rep 2010, 24: 89-95.

[55] HEALD B, MESTER J, RYBICKI L, ORLOFF MS, BURKE $\mathrm{CA}$, et al: Frequent gastrointestinal polyps and colorectal adenocarcinomas in a prospective series of PTEN mutation carriers. Gastroenterology 2010, 139: 1927-1933. http:// dx.doi.org/10.1053/j.gastro.2010.06.061

[56] ABBASZADEGAN MR, MOAVEN O, SIMA HR, GHAFARZADEGAN K, A'RABI A, et al: p16 promoter hypermethylation: a useful serum marker for early detection of gastric cancer. World J Gastroenterol 2008, 14: 2055-2060. http://dx.doi. org/10.3748/wjg. 14.2055

[57] WIDSCHWENDTER A, MULLER HM, FIEGL H, IVARSSON L, WIEDEMAIR A, et al: DNA methylation in serum and tumors of cervical cancer patients. Clin Cancer Res 2004, 10: 565-571. http://dx.doi.org/10.1158/1078-0432.CCR-0825-03

[58] WANG J, QIN Y, LI B, SUN Z, YANG B: Detection of aberrant promoter methylation of GSTP1 in the tumor and serum of Chinese human primary hepatocellular carcinoma patients. Clin Biochem 2006, 39: 344-348. http://dx.doi.org/10.1016/j. clinbiochem.2006.01.008

[59] SKVORTSOVA TE, RYKOVA EY, TAMKOVICH SN, BRYZGUNOVA OE, STARIKOV AV, et al: Cell-free and cell-bound circulating DNA in breast tumours: DNA quantification and analysis of tumour-related gene methylation. Br J Cancer 2006, 94(: 1492-1495. 
[60] MORI T, O'DAY SJ, UMETANI N, MARTINEZ SR, KITAGO $\mathrm{M}$, et al: Predictive utility of circulating methylated DNA in serum of melanoma patients receiving biochemotherapy. J Clin Oncol 2005, 23: 9351-9358. http://dx.doi.org/10.1200/ LCO.2005.02.9876

[61] LANGE CP, LAIRD PW: Clinical applications of DNA methylation biomarkers in colorectal cancer. Epigenomics 2013, 5: 105-108. http://dx.doi.org/10.2217/epi.13.4

[62] HIBI K, GOTO T, SHIRAHATA A, SAITO M, KIGAWA G, et al: Detection of TFPI2 methylation in the serum of gastric cancer patients. Anticancer Res 2011, 31: 3835-3838.

[63] LU XX, YU JL, YING LS, HAN J, WANG S, YU QM, et al: Stepwise cumulation of RUNX3 methylation mediated by Helicobacter pylori infection contributes to gastric carcinoma progression. Cancer 2012, 118: 5507-5517. http://dx.doi. org/10.1002/cncr.27604

[64] SAPARI NS, LOH M, VAITHILINGAM A, SOONG R: Clinical potential of DNA methylation in gastric cancer: a meta-analysis. PLoS One 2012, 7: e36275. http://dx.doi. org/10.1371/journal.pone.0036275

[65] BERNAL C, AGUAYO F, VILLARROEL C, VARGAS M, DIAZ I, et al: Reprimo as a potential biomarker for early detection in gastric cancer. Clin Cancer Res 2008, 14: 6264-6269. http://dx.doi.org/10.1158/1078-0432.CCR-07-4522

[66] CHEUNG KF, LAM CN, WU K, NG EK, CHONG WW, et al: Characterization of the gene structure, functional significance, and clinical application of RNF180, a novel gene in gastric cancer. Cancer 2012, 118: 947-959. http://dx.doi.org/10.1002/ cncr.26189

[67] LEE TL, LEUNG WK, CHAN MW, NG EK, TONG JH, et al: Detection of gene promoter hypermethylation in the tumor and serum of patients with gastric carcinoma. Clin Cancer Res 2002, 8: 1761-1766.

[68] CHENG YY, YU J, WONG YP, MAN EP, TO KF, et al: Frequent epigenetic inactivation of secreted frizzled-related protein 2 (SFRP2) by promoter methylation in human gastric cancer. Br J Cancer 2007, 97: 895-901. http://dx.doi. org/10.1038/sj.bjc.6603968

[69] ABBASZADEGAN MR, MOAVEN O, SIMA HR, GHAFARZADEGAN K, A'RABI A, et al:p16 promoter hypermethylation: a useful serum marker for early detection of gastric cancer. World J Gastroenterol 2008, 14: 2055-2060. http://dx.doi. org/10.3748/wjg.14.2055

[70] ZOU XP, ZHANG B, ZHANG XQ, CHEN M, CAO J, et al: Promoter hypermethylation of multiple genes in early gastric adenocarcinoma and precancerous lesions. Hum Pathol 2009, 40: 1534-1542. http://dx.doi.org/10.1016/j. humpath.2009.01.029

[71] TAMURA G: Promoter methylation status of tumor suppressor and tumor-related genes in neoplastic and non-neoplastic gastric epithelia. Histol Histopathol 2004, 19(1): 221-228.

[72] ZHAO C, BU X: Promoter methylation of tumor-related genes in gastric carcinogenesis. Histol Histopathol 2012, 27: 1271-1282.

[73] CALIN GA, CROCE CM: MicroRNA signatures in human cancers. Nat Rev Cancer 2006, 6: 857-866. http://dx.doi. org/10.1038/nrc1997
[74] ESQUELA-KERSCHER A, SLACK FJ: Oncomirs - microRNAs with a role in cancer. Nat Rev Cancer 2006, 6: 259-269. http://dx.doi.org/10.1038/nrc1840

[75] NICOLOSO MS, SPIZZO R, SHIMIZU M, ROSSI S, CALIN GA: MicroRNAs-the micro steering wheel of tumour metastases. Nat Rev Cancer 2009, 9: 293-302. http://dx.doi. org/10.1038/nrc2619

[76] CORTEZ MA, BUESO-RAMOS C, FERDIN J, LOPEZBERESTEIN G, SOOD AK, et al: MicroRNAs in body fluids--the mix of hormones and biomarkers. Nat Rev Clin Oncol 2011, 8: 467-477. http://dx.doi.org/10.1038/nrclinonc. 2011.76

[77] LAWRIE CH, GAL S, DUNLOP HM, PUSHKARAN B, LIGGINS AP, et al: Detection of elevated levels of tumourassociated microRNAs in serum of patients with diffuse large B-cell lymphoma. Br J Haematol 2008, 141: 672-675. http:// dx.doi.org/10.1111/j.1365-2141.2008.07077.x

[78] ASAGA S, KUO C, NGUYEN T, TERPENNING M, GIULIANO AE, et al: Direct serum assay for microRNA-2 1 concentrations in early and advanced breast cancer. Clin Chem 2011, 57: 84-91. http://dx.doi.org/10.1373/ clinchem.2010.151845

[79] NG EK, CHONG WW, JIN H, LAM EK, SHIN VY, et al: Differential expression of microRNAs in plasma of patients with colorectal cancer: a potential marker for colorectal cancer screening. Gut 2009, 58: 1375-1381. http://dx.doi. org/10.1136/gut.2008.167817

[80] YAMAMOTO Y, KOSAKA N, TANAKA M, KOIZUMI F, KANAI Y, et al: MicroRNA-500 as a potential diagnostic marker for hepatocellular carcinoma. Biomarkers 2009, 14: 529-538. http://dx.doi.org/10.3109/13547500903150771

[81] UEDA T, VOLINIA S, OKUMURA H, SHIMIZU M, TACCIOLI C, et al: Relation between microRNA expression and progression and prognosis of gastric cancer: a microRNA expression analysis. Lancet Oncol 2010, 11: 136-146. http:// dx.doi.org/10.1016/S1470-2045(09)70343-2

[82] ICHIKAWA D, KOMATSU S, KONISHI H, OTSUJI E: Circulating microRNA in digestive tract cancers. Gastroenterology 2012, 142: 1074-1078 e1071.

[83] TSUJIURA M, ICHIKAWA D, KOMATSU S, SHIOZAKI A, TAKESHITA $\mathrm{H}$, et al: Circulating microRNAs in plasma of patients with gastric cancers. Br J Cancer 2010, 102: 1174-1179. http://dx.doi.org/10.1038/sj.bjc.6605608

[84] LIU R, ZHANG C, HU Z, LI G, WANG C, et al: A fivemicroRNA signature identified from genome-wide serum microRNA expression profiling serves as a fingerprint for gastric cancer diagnosis. Eur J Cancer 2011, 47: 784-791. http://dx.doi.org/10.1016/j.ejca.2010.10.025

[85] LIU H, ZHU L, LIU B, YANG L, MENG X, et al: Genomewide microRNA profiles identify miR-378 as a serum biomarker for early detection of gastric cancer. Cancer Lett 2012, 316: 196-203. http://dx.doi.org/10.1016/j.canlet.2011.10.034

[86] LI BS, ZHAO YL, GUO G, LI W, ZHU ED, et al: Plasma microRNAs, miR-223, miR-21 and miR-218, as novel potential biomarkers for gastric cancer detection. PLoS One 2012, 7: e41629. http://dx.doi.org/10.1371/journal.pone.0041629 
[87] YUASA Y: Control of gut differentiation and intestinal-type gastric carcinogenesis. Nat Rev Cancer 2003, 3: 592-600. http://dx.doi.org/10.1038/nrc1141

[88] ROTKRUA P, SHIMADA S, MOGUSHI K, AKIYAMA $\mathrm{Y}$, TANAKA $\mathrm{H}$, et al: Circulating microRNAs as biomarkers for early detection of diffuse-type gastric cancer using a mouse model. Br J Cancer 2013, 108: 932-940. http://dx.doi. org/10.1038/bjc.2013.30

[89] KONISHI H, ICHIKAWA D, KOMATSU S, SHIOZAKI A, TSUJIURA M, et al: Detection of gastric cancer-associated microRNAs on microRNA microarray comparing pre- and post-operative plasma. Br J Cancer 2012, 106: 740-747. http:// dx.doi.org/10.1038/bjc.2011.588

[90] SONG MY, PAN KF, SU HJ, ZHANG L, MA JL, et al: Identification of serum microRNAs as novel non-invasive biomarkers for early detection of gastric cancer. PLoS One 2012, 7: e33608. http://dx.doi.org/10.1371/journal.pone.0033608

[91] LI C, LI JF, CAI Q, QIU QQ, YAN M, et al: miRNA-199a$3 p$ in plasma as a potential diagnostic biomarker for gastric cancer. Ann Surg Oncol 2013, 20 Suppl 3: S397-405. http:// dx.doi.org/10.1245/s10434-012-2600-3

[92] KOSAKA N, IGUCHI H, OCHIYA T: Circulating microRNA in body fluid: a new potential biomarker for cancer diagnosis and prognosis. Cancer Sci 2010, 101: 2087-2092. http://dx.doi. org/10.1111/j.1349-7006.2010.01650.x

[93] HU Z, DONG J, WANG LE, MA H, LIU J, et al: Serum microRNA profiling and breast cancer risk: the use of miR-484/191 as endogenous controls. Carcinogenesis 2012, 33: 828-834. http://dx.doi.org/10.1093/carcin/bgs030

[94] SONG J, BAI Z, HAN W, ZHANG J, MENG H, et al: Identification of suitable reference genes for qPCR analysis of serum microRNA in gastric cancer patients. Dig Dis Sci 2012, 57: 897-904. http://dx.doi.org/10.1007/s10620-011-1981-7

[95] BLONDAL T, JENSBY NIELSEN S, BAKER A, ANDREASEN D, MOURITZEN P, et al: Assessing sample and miRNA profile quality in serum and plasma or other biofluids. Methods 2013, 59: S1-6. http://dx.doi.org/10.1016/j. ymeth.2012.09.015

[96] UMETANI N, GIULIANO AE, HIRAMATSU SH, AMERSI F, NAKAGAWA T, et al: Prediction of breast tumor progression by integrity of free circulating DNA in serum. J Clin Oncol 2006, 24: 4270-4276. http://dx.doi.org/10.1200/ JCO.2006.05.9493

[97] HAYES DN, KIM WY: The next steps in next-gen sequencing of cancer genomes. J Clin Invest 2015, 125: 462-468. http:// dx.doi.org/10.1172/JCI68339

[98] IGNATIADIS M, DAWSON SJ: Circulating tumor cells and circulating tumor DNA for precision medicine: dream or reality? Ann Oncol 2014, 25: 2304-2313. http://dx.doi. org/10.1093/annonc/mdu480

[99] DANG Y, WANG YC, HUANG QJ: Microarray and nextgeneration sequencing to analyse gastric cancer. Asian Pac J Cancer Prev 2014, 15: 8033-8039. http://dx.doi.org/10.7314/ APJCP.2014.15.19.8035 